\title{
"It is as if you were taking a shot in the dark": Experiencing ambiguity in the pharmacological treatment of rheumatoid arthritis
}

\author{
"É como se você estivesse dando um tiro no escuro": Vivenciando a ambiguidade no tratamento \\ farmacológico da artrite reumatoide
}

"Es como un tiro en la oscuridad": Viviendo la ambiguiedad en el tratamiento farmacológico de la artritis reumatoide

Received: 06/11/2021 | Reviewed: 07/08/2021 | Accept: 07/16/2021 | Published: 07/19/2021

Carina de Morais Neves

ORCID: https://orcid.org/0000-0002-8759-9559 Federal University of Minas Gerais, Brazil

E-mail: carinamneves@gmail.com

Yone de Almeida Nascimento

ORCID: https://orcid.org/0000-0002-5897-0160 Federal University of Minas Gerais, Brazil

E-mail: yone.almeida1@gmail.com

Mariana Martins Gonzaga do Nascimento ORCID: https://orcid.org/0000-0003-2183-4365

Federal University of Minas Gerais, Brazil

E-mail: marianamgn@yahoo.com.br

Hágabo Mathyell Silva

ORCID: https://orcid.org/0000-0002-2458-1837

Federal University of Minas Gerais, Brazil

E-mail: hagaboms@gmail.com

Isabela Viana Oliveira

ORCID: https://orcid.org/0000-0001-7846-5914

Federal University of Minas Gerais, Brazil

E-mail: isabelaviana.far@gmail.com

Simone de Araújo Medina Mendonça

ORCID: https://orcid.org/0000-0001-5792-0682

Federal University of Minas Gerais, Brazil

E-mail: simoneamm@gmail.com

Adriana Maria Kakehasi

ORCID: https://orcid.org/0000-0001-9411-7493

Federal University of Minas Gerais, Brazil

E-mail: mkakehasi@gmail.com

Djenane Ramalho-de-Oliveira

ORCID: https://orcid.org/0000-0002-5548-8184

Federal University of Minas Gerais, Brazil

E-mail: djenane.oliveira@gmail.com

\begin{abstract}
Rheumatoid arthritis (RA) is a chronic disease that compromises patients' quality of life and it demands an indispensable and complex pharmacological treatment. The aim of the present study was to understand patients' experiences with the pharmacological treatment of RA. In order to explore this area, interviews were conducted with patients with RA followed at an outpatient clinic. Merleau-Ponty's theoretical framework was applied to understand the investigated phenomenon by using the essential structures of the experience (time, space, relationships with other people, and sexuality, all of which are anchored in the body). These were used to describe the central meanings of the patients' medication experience. The data showed that patients experienced ambiguity during the RA treatment and that it pervaded all the essential structures of the experience. The experiences that emerged from data analysis were: "waiting for the proper treatment"; "hoping for its effectiveness and safety"; "rediscovering spaces lost because of the disease"; and "self-management in controlling
\end{abstract}


symptoms". Understanding these experiences allows for the healthcare team to offer more comprehensive, holistic and effective care, contributing to better health outcomes.

Keywords: Rheumatoid arthritis; Qualitative research; Patient experience.

\begin{abstract}
Resumo
A artrite reumatoide (AR) é uma doença crônica que compromete a qualidade de vida dos pacientes e requer um tratamento farmacológico indispensável e complexo. O objetivo do presente estudo foi compreender as experiências dos pacientes com o tratamento farmacológico da AR. Para tal, foram realizadas entrevistas em profundidade com indivíduos atendidos em um ambulatório. O referencial teórico de Merleau-Ponty foi aplicado para compreender o fenômeno investigado por meio das estruturas essenciais da experiência (tempo, espaço, relação com o outro e sexualidade). Os dados revelaram que os pacientes experienciam de forma mais significativa a ambiguidade durante o tratamento, e esta perpassa todas as estruturas essenciais, ressaltando a experiência da espera pelo tratamento adequado, pela sua efetividade e segurança, a redescoberta dos espaços perdidos com a doença e o autogerenciamento no controle dos sintomas. Compreender essas experiências proporciona a prestação de um cuidado mais integral, holístico e efetivo contribuindo para melhora dos resultados em saúde.
\end{abstract}

Palavras-chave: Artrite reumatoide; Pesquisa qualitativa; Experiência do paciente.

\title{
Resumen
}

La artritis reumatoide (AR) es una enfermedad crónica que compromete la calidad de vida de los pacientes y exige un tratamiento farmacológico indispensable y complejo. El objetivo del presente estudio fue comprender las experiencias de los pacientes con el tratamiento farmacológico de la AR. Para explorar esta área, se realizaron entrevistas con pacientes con AR seguidos en un ambulatorio. Se aplicó el marco teórico de Merleau-Ponty para comprender el fenómeno investigado utilizando las estructuras de la existencia (tiempo, espacio, relaciones con otras personas y sexualidad, todos ellos anclados en el cuerpo). Estos se utilizaron para describir los significados centrales de la experiencia con la medicación de los pacientes. Los datos mostraron que los pacientes experimentaron ambigüedad durante el tratamiento de la AR y que impregnaba todas las estructuras esenciales de la experiencia. Las experiencias que surgieron del análisis de datos fueron: "esperando el tratamiento adecuado"; "esperando su eficacia y seguridad"; "redescubriendo espacios perdidos por la enfermedad"; y "autogestión para controlar los síntomas". Comprender estas experiencias permite que el equipo de atención em salud ofrezca una atención más integral, holística y eficaz, contribuyendo a mejores resultados en salud.

Palabras-clave: Artritis reumatoide; Investigación cualitativa; Experiencia del paciente.

\section{Introduction}

Rheumatoid arthritis (RA) is an autoimmune chronic disease that affects joints and compromises patients' quality of life (Brasil et al., 2017; Mota et al., 2018; Singh et al., 2016; Smolen et al., 2017). In Brazil, its prevalence is 0.5\%, representing nearly one million patients, which are mostly women (Senna et al., 2004).

The treatment of RA involves non-pharmacological (eg. exercises, physical therapy) and pharmacological treatments. The later tend to be complex and usually is composed of different medications such as painkillers, anti-inflammatories, and the socalled disease-modifying antirheumatic drugs (DMARDs), which control the disease activity, prevent damage to the joints and complications. DMARDS have the capacity to improve functional capacity and, therefore, must be introduced as soon as the diagnosis is established (Brasil et al., 2017; Mota et al., 2018; Singh et al., 2016; Smolen et al., 2017).

The use of medications is a complex phenomenon and pose a challenge for health care professionals, especially when multiple drugs are being managed, like in the RA treatment. During their clinical practice, they often come across specific situations related to the diverse ways in which patients experience the use of medications (Ramalho De Oliveira, 2011). To name these processes, the term medication experience was coined, and it is defined as the subjective experiences that people live through in their daily life when using medications (Shoemaker \& Ramalho De Oliveira, 2008). This experience can 
Research, Society and Development, v. 10, n. 9, e0110917071, 2021

(CC BY 4.0) | ISSN 2525-3409 | DOI: http://dx.doi.org/10.33448/rsd-v10i9.17071

significantly impact patients' decisions regarding treatment, lead to drug therapy problems and impact on their clinical results (Ramalho De Oliveira, 2009; Ramalho De Oliveira, Shoemaker, Ekstrand \& Alves, 2012).

Studies regarding the chronic use of medications have shown both negative experiences, which resulted in non-adherence to treatment and difficulty in controlling the disease; and positive experiences, which showed that drugs helped bring life back to normal (Alves, 2012; Craftman, Westerbotn, Strauss, Hilleras \& Hammar, 2015; Devlen et al., 2014; Gibson, 2016; Kobue, Moch, \& Watermeyer, 2017; Kumar et al.,2011; Meyfroidt et al., 2015; Nascimento, Filardi, Abath, Silva \& Ramalho-DeOliveira, 2017; Nascimento, Silva \& Ramalho De Oliveira, 2019; Pinter et al., 2017). Nascimento et al. (2019) showed that medications promote changes in the physical and in the phenomenal body (this involves the experiences through which people interact with the world). They also identified four ways to experience the chronic use of medications: ambiguity, resolution, adversity, and irrelevance (Nascimento et al., 2019).

Specifically in RA, studies that focused on patients' experiences with the disease found ambiguous perceptions towards medications' effectiveness and safety (Brandstetter, Hertig, Loss, Ehrenstein \& Apfelbacher, 2016). However, no previous study evaluated patients' medication experience with the complex AR pharmacological treatment. Given this scenario, it is important to understand how the experiences shown in the patients' own narratives shape their behaviors towards the RA pharmacotherapy, including the motivations that lead them to adhere or not to the treatment. In this context, the present study had the objective of understanding RA patients' medication experiences.

\section{Methodology}

\subsection{Study design}

In the present study, the qualitative paradigm was used, because the objective is not to measure, but to understand how the object of the study is manifested, and, in this case, to explore the medication experiences of patients with RA. The qualitative approach is generally focused on the discovery, identification, in-depth description and development of theories related to a phenomenon, being considered the most appropriate method for understanding social phenomena and for a deep exploration of individual experiences (Santos, 1999). Therefore, the results from qualitative studies reveal the meaning that the phenomenon gains for those who experience it, making an important contribution in the field of health to better understand the lives of patients and the phenomena related to their diseases. These meanings have a structuring function, since individuals organize their lives, including their health care based on the meanings they attribute to the disease and its treatment (Turato, 2005).

The authors used phenomenology as a methodological path. Acording to Merleau-Ponty: "phenomenology is not the study of certain purely abstract essences, such as Plato's forms. The essences that phenomenology studies are, rather, instruments in our attempt to understand our own lives in the world". (Merleau-Ponty, 2202: XVI; Matthews, 2011, p. 29). There are several currents of thought in the phenomenology sphere, and the philosopher Merleau-Ponty contributed to the field by pointing out the role that the body plays in one's existence. He also discussed how the perturbation of the relationship between the body and the world deeply unsettles existence. Previous studies using this theoretical framework showed that the use of medications changes both the patients' physical and phenomenal body (Nascimento et al. 2017; 2019). Thus, the present study also resorted to this theoretical framework to delve into the experiences of patients living with RA and their medication use.

\subsection{Sample}

The present investigation was conducted at the Rheumatoid Arthritis Outpatient Clinic of the Rheumatology at a public teaching hospital in the state of Minas Gerais. It presents the results of the master's degree research developed by the 
first author after it was approved by the Research Ethics Committee of the Federal University of Minas Gerais (CAAE number: 25780314.4.0000.5149). All patients who participated in the study signed informed consent forms.

During an outpatient survey, prior to this study, one of the researchers screened patients 18 years or older with RA diagnosis according to the criteria of the American College of Rheumatology (1997) and the European League Against Rheumatism (2010), who were using medications for this condition and who could provide rich, pertinent, and diverse accounts of these experiences. Those who agreed to participate were invited by telephone or during face-to-face conversations and signed free and informed consent forms.

The confidentiality of the information was guaranteed and the identity of all participants was kept unknown. To describe and characterize the subjects of the present study - with RA using chronic medications for this condition - the name of precious stones was used as a codename to identify them. This choice was certainly not by chance and is the result of the transformation that their narratives produced in the authors and the meaning revealed through their stories: resilience (such as stones, human beings, during life, go through complex processes, acquiring the ability to adapt to face and overcome life's adversities).

The data were collected through the in-depth interview, which is a qualitative research technique that involves conducting intense, detailed and rich individual interviews with a small number of respondents to explore their experiences (Minayo, 2014). The interviews were conducted at the rheumatology outpatient clinic from April 2018 to January 2019. The patients' experiences with their pharmacological treatment of RA were explored by introducing two guiding questions: "How did you feel when you found out that you had RA and that you would have to use medication continuously?" and "Tell me about your experience with the RA treatment". In order to test the guiding questions, two initial interviews were conducted, but these were not included in the data analysis.

Patients who took long-term medications for RA participated in individual interviews, that lasted an average of 25 min and were recorded and fully transcribed. At the end of thirteen interviews, data began to repeat itself, without the emersion of any new meaning units. To confirm data saturation, that is, the time at which data collection does not show new meanings an additional interview was conducted by one of the researchers, showing that the essence of the experience had already been captured by previous data collection. Phenomenological research accepts a small sample of participants, as reported by Creswell (1998) and Polit \& Beck (2004) in their work, in which ten participants are sufficient, but this number is usually determined when data saturation is reached. Saturation is considered one of the most accepted criteria in which intentional sample sizes are determined in health sciences research (Guest, Buncen \& Johnson, 2006).

The data from the interviews were complemented by the notes taken in the field diary, carried out by the first author during and after the interviews. These notes allowed the researcher to register her personal impressions and ideas, as well as the participants' nonverbal behaviors. These notes were also used in the data analysis.

\subsection{Data analysis}

In phenomenological research, there are three instances when analysis is carried out: description, reduction, and understanding (Corrêa, 1997). Description began with the transcription of the interviews. Then thematic analysis was performed, aiming to achieve a comprehensive understanding of the phenomenon by carrying out a rich and in-depth reading of the interviews and the field diary. In this stage, it was also used a selective approach, or line by line analysis, which involved an extensive reading to identify statements that added meaning to the participants' experience. 
NVivo 11 (qualitative data analysis software) was used to help organize and identify the essence of the narratives. After pinpointing the main meaning units, the narratives were read again to perform a new analysis; this process was repeated several times so that better quality and credibility could be achieved (Kvigne \& Kirkevold, 2003).

The phenomenological reduction step consisted of obtaining the essence of the experiences by putting the researcher's assumptions, beliefs, and theories about the examined phenomenon in suspension. It was also the time to choose what was essential in the description and what was not by applying imaginative variation, by which "the researcher thinks of each part as being present or absent in the experience, until the description is reduced to what is essential for the existence of the consciousness of the experience" (Corrêa, 1997, p. 86).

Merleau-Ponty's theoretical framework was applied to understand the investigated phenomenon by using the structures of existence (time, space, relationships with other people, and sexuality, all of which are anchored in the body). According to the philosopher, our existence is understood through our body, and our experiences are anchored in it. The body, therefore, is not only a body to be observed, but it is something that we experience and that is essential to our involvement with the world; it is our means of communication with it. In this way, it is always a "lived body", and, in this sense, the philosopher says: "the world is not what I think, but what I live" (Merleau-Ponty, 2011). Our attitudes are not merely responses to external stimuli, but as subjects, we have desires and certain needs that lead us to act in a certain way, so our subjectivity is expressed in our body (Matthews, 2011). The structures of existence used as guides to describe the central meanings of the patients' medication experiences.

The structure of "Time" is one of the most important structures in Merleau-Ponty's perspective. It can be seen objectively and in a measurable way regarding its chronology, but also as subjective or phenomenal. It consists of past, present, and future; and, therefore, it only exists if there are people capable of experiencing it (Matthews, 2011).

"Space" is the environment in which the existence and positioning of objects become possible. However, it is also defined by the tasks and situations associated with it. As embodied beings, people are where they are because they have something to execute there. Additionally, affection for a place is closely related to the experience one can have in that space (Merleau-Ponty, 2011; Matthews, 2011).

The "relationship with others" is a structure that embraces the fact that no one lives in isolation; everyone is in constant interaction and communication with others. Thus, different perspectives coexist as well as the common meanings that are shared by individuals regarding the objects around them (Berger \& Luckmann, 2013; Nascimento et al., 2017). MerleauPonty believed in the benefits of connecting and interacting with other people and saw in dialogue a potential mean through which people gain knowledge and validation. According to the philosopher, life happens in a relationship network, and other people are seen as travel companions in life's journey (Cypress, 2011).

Regarding the "sexuality" structure, Merleau-Ponty days that it is the individual's form of existence in the world, and, through sexuality they have an identity and build their history. In this sense, it cannot be conceived as an exclusively genital element. "It is the general power that the psychophysical subject has to adhere to different environments, to settle for different experiences, to acquire structures of conduct. It is sexuality that makes a man have a history” (Merleau-Ponty, 2011, p. 219). 


\section{Results and Discussion}

The patients experienced ambiguity during the RA treatment and that it pervaded all the essential structures of the experience (Figure 1).

Figure 1. Essential structures of the experience in the pharmacological treatment of rheumatoid arthritis.

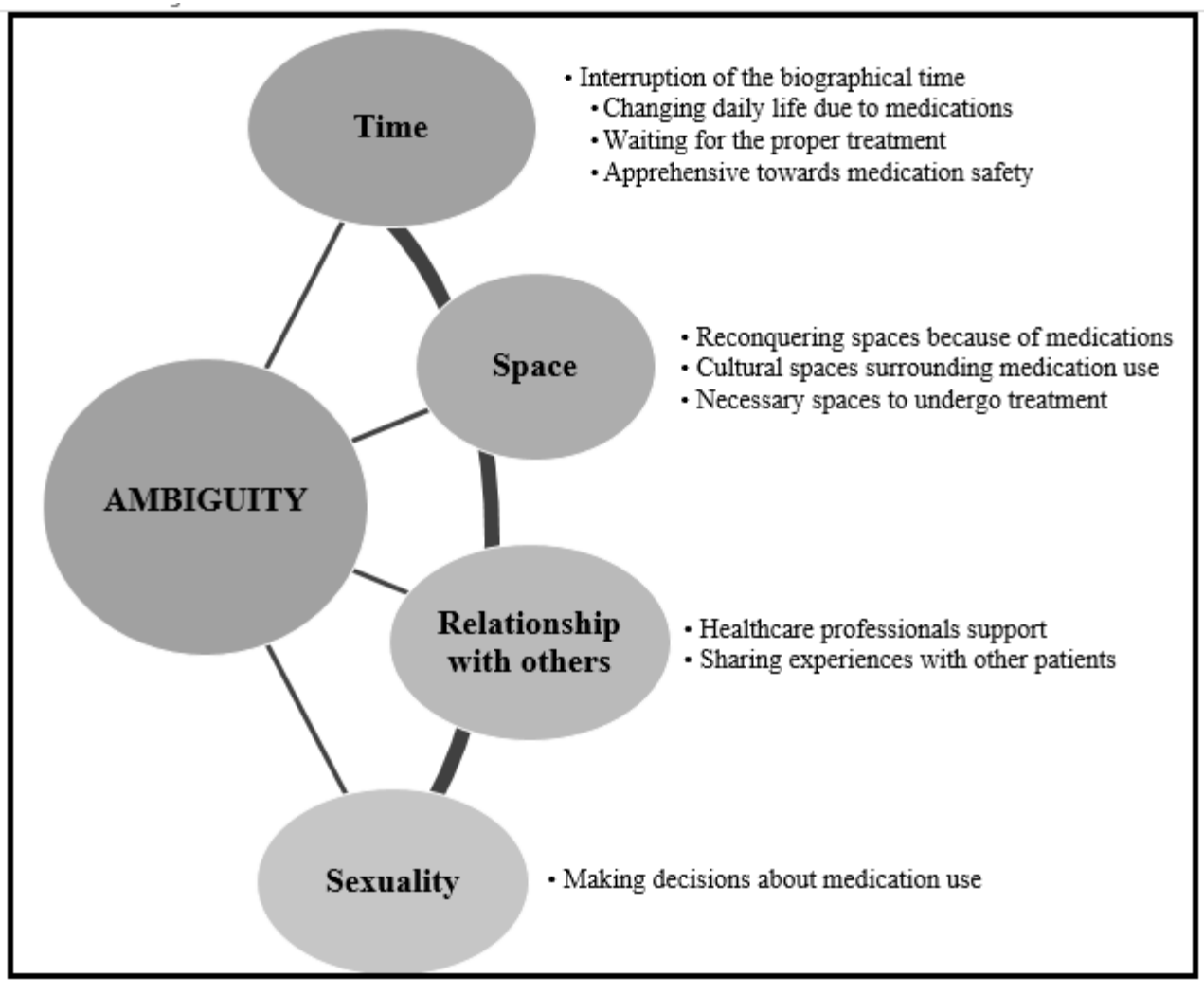

Source: Authors.

\subsection{The experience of time}

The "experience of time" manifested itself though the interruption of the biographical time of the participants. This interruption was caused by the changes in daily life due to medications use; by the wait for a proper treatment; and by the apprehensiveness towards its safety.

Emerald remembered that she used to have good health before being diagnosed and starting to taking medications continuously: "Up to that time, I was a very healthy person. It was not like me to take medications nonstop because of any simple problem. That's why it was so difficult for me in the beginning." In this perspective, disease invades human life and the interruption of their biographical time is felt. People often compare their present and future body to the past one, which leads them to a deep feeling of loss and identity change (Devins, 1994). For Emerald, taking medications reminds them of the presence of the disease and leave behind the memories of who they once were. This disruption in time and the mourning involved in this process must be properly addressed by the health team, since this can negatively impact adherence to pharmacotherapy.

Emerald reported her initial difficulty in dealing with the use of several medications: "Back then, I would ask myself: did I take this medication today? Am I late? I wondered if I had taken it or not. (...) I got confused!” On the other hand, Turquoise seemed to have incorporated medication use into her daily routine more naturally: "I am already used to it; it's a normal thing. Is like having breakfast, taking a shower..." 
Chronic conditions usually demand a complex regimen for their control that, in turn, requires daily self-care (Kobue, Moch \& Watermeyer, 2017). Therefore, the continuous nature of medication use changes daily routines, which is also construed as a burden in patients' lives (Shoemaker \& Ramalho De Oliveira, 2008). Consequently, patients often report that it takes a few years for them to adapt to the medication use process, until it becomes a compromise and a habit (Brandester, Hertig, Loss, Ehrenstein \& Apfelbacher et al., 2016; Dohnammar, Reeve \& Walley, 2016; Todd et al., 2016). It is important, therefore, to take these factors into account when defining the ideal dosage in an individualized way for each patient's routine, thus reducing the time for adjusting to the established pharmacological treatment.

The continuous wait for a proper treatment also pervades the lives of individuals with RA. The patients declared that they had many difficulties accessing a rheumatologist and, therefore, they had to wait to gain access to a treatment that actually changed the progress of the disease, as emphasized by Alexandrite:

"I began getting very ill when I was 19, but only I started to be treated here when I was nearly 30 . Now, I am 65 . In the meantime, the doctor would pres"cribe me aspirin and would not request any tests. He would just say that it was rheumatism. But which rheumatism was it? I had no control because no follow-up was even scheduled" (Alexandrite).

Studies have shown that only $22 \%$ to $31 \%$ of patients with RA are evaluated by a rheumatologist within 12 weeks after the beginning of the symptoms (Cock et al., 2014; Raza et al., 2011), and usually an exhausting journey to search for symptom relief is taken before it is actually achieved (Salt \& Peden, 2011).

Additionally, DMARDs have been developed only recently (Hofman et al., 2015), which means few therapeutic options were available at the beginning of the treatment for many patients. On the other hand, physicians who are not rheumatologists are not used to prescribing DMARDs and do not feel comfortable doing so because of lack of experience with these drugs (Kalkan, Hoback, Hallert \& Carlsson, 2014). It is recommended that therapy with DMARDs be initiated as soon as the diagnosis is established, given that early access to these medications can drastically change the progress of the disease (Brazil, 2017; Hayden, Neame \& Tarrant, 2015; Mota et al., 2018; Salt \& Peden, 2011; Singh et al., 2016; Smolen et al., 2016;) and increase the possibility of a sustainable remission (Aken et al., 2004; Bykerk \& Emery, 2010; Lard et al., 2001; Linden et al., 2010; Nell et al., 2004).

The interviewees also talked about the wait to find out about the effectiveness and safety of the medications they used. In the present study, all patients had already experienced at least two substitutions in their drug therapy, in addition to constant adjustments in dosages or medication schedules. Every time there was a change in the drug therapy, the patients experienced great expectations regarding the improvement of the disease symptoms and the interruption of adverse effects. During this process, uncertainty was illustrated in the narrative of Quartz, who had already experienced several medication changes:

"The results come and go and there is no definition. One thing is knowing that you are taking a medication and that you will be well soon. Another thing is knowing that you are taking a medication and that you may get better or worse... There is no certainty. It is as if you were taking a shot in the dark" (Quartz).

In a study by Kumar et al. (2011), patients reported that they did not understand the reasons for frequent changes in their therapy. Some patients expressed the opinion that the trust in their treatment decreases when it is changed many times or when the medications are effective only for a short period (Prothero et al., 2016; Salt \& Peden, 2011; Shaw et al., 2018). This uncertainty is associated with the feeling of loss of control, shown in the experience with the use of continuous medications examined by Shoemaker and Ramalho de Oliveira (2008). In this context, the importance of involving the patient in the 
decision-making process and empowering them about the reasons for the changes and adjustments in the treatment must be highlighted.

Additionally, the patients took their medications fearfully, always waiting for a possible negative outcome. Sapphire, that experienced multiple substitutions in her pharmacotherapy because of safety problems, illustrates that:

"For instance, I got worried about my sight. Chloroquine is an example. I had to stop taking it. Also, too many antiinflammatory drugs, you know. After some time, it affected my liver. (...) There are many medications that I cannot take because of my liver. So, you take a medicine to treat one thing and harm another" (Sapphire).

The fear of the interruption of life itself was pointed out by Emerald, that talked about the first time she read the informed consent form to use a biological DMARD: "The first time I took it, I said: I am going to die! That medication could suddenly cause me something else. My heartbeat could increase... If I felt anything, I had to go to the emergency department. It was a time bomb!"

\subsection{The experience of space}

In this study, the "experience of space" can be described from several perspectives: the rediscovery of the spaces lost because of the disease; the cultural space that surrounds the use of medications; and the space necessary to undergo treatment.

The participants showed their feelings of helplessness, disability, incapacity, and unproductiveness originating from the disease and, because of this, they experienced space significantly. However, the medications brought new meaning, given that they provided them with normalization of life, allowing them to rediscover the spaces lost because of the disease. This is illustrated in Sapphire's speech, that recognizes the importance of the medications:

"If it were not for these medications, I would not even be able to walk. When I used to wake up, most of the times, I had to lean against the wall. I could not get out of bed and walk. Since then, with these new medicines... I am much better" (Sapphire).

Topaz points out the medications as a salvation: "The medicines help, a lot. Otherwise, I would not be able to work! Salvation, right? That's what they are! The difficulties caused by the symptoms of the disease, its unstable nature are associated with high rates of occupational disability, with $20 \%$ to $70 \%$ of the people being considered disabled after a period of seven to ten years after RA initial diagnosis (Holland \& Collins, 2016).

There is increasing evidence demonstrating that the use of DMARDs optimizes clinical results, with improvement of pain, edema, and stiffness (Brasil, 2017; Mota et al., 2018; Singh et al., 2016; Smolen et al., 2016;). Patients have reported that they felt remarkable changes in their physical symptoms, which causes them to experience improvement in quality of life and, consequently, a return to social and productive life (Arkell, Ryan, Brownfield, Cadwgan \& Packham et al., 2013; Baker, Isaacs \& Thompson, 2019; Feldman, Hicks, Norton, Freeman \& Solomon et al., 2013; Hewlett et al., 2019; Lindén \& Bjorklund, 2010; Marshall, Wilson, Lapworth \& Kay 2004; Sanders et al., 2017).

On the other hand, the participants' experiences can also be understood through the cultural space in which human beings are inserted and by which they are influenced. In this space, medications take on the symbolism of "drugs", since they can cause harm: 
"We get worried. What is going to happen? I am aware that the medication is a drug. Over time, they make it clear to us: you are treating something, but that medication can cause you a reaction. So, we take the medication with fear" (Quartz).

Diamond mentions how his physical and phenomenal body suffered from feeling dependent and imprisoned by the use of medication: "Who wants to be dependent? Everyone wants to be free! And I would really like to get rid of this! It is like you're stuck. You know? As if you were being driven; your life being steered."

Amongst the barriers that lead patients to not take their medications is the fear of developing dependence (Kobue, Moch \& Watermeyer, 2017; Pound et al., 2005), illustrated in the speech of Quartz and Diamond (Angermeyer, Loffler, Muller, Schulze \& Priebe, 2001). Thus, in addition to the need to have a system and qualified professionals that allow early access to effective treatment, which has already been highlighted previously, it is also necessary to validate the positive and negative experiences of each patient, not only empathetically by the health care team, but also in spaces that allow exchanges between patients.

The interviews mentioned how healthcare settings are associated with the burden of the treatment. Healthcare settings (hospitals, laboratories, pharmacies) are spaces that are needed in order to guarantee the RA treatment, but greatly affect their lives:

"There are those restrictions: come to the hospital, come to the appointment... Tomorrow I will be here all day long to get a drug infusion! This afternoon I will do densitometry, then I will have an appointment with another doctor. This gets in the way of getting a job, because no business will hire someone who needs to be absent at least twice a month to take care of their health. And there lies the problem: I need to work and I need to treat my condition!” (Agate).

This was also identified in a study by Nascimento et al. (2019) with chronic hepatitis C patients; and in an investigation by Baker, Isaacs, and Thompson (2019), in which the need to go to medical appointments, to the pharmacy, and the difficulties of transporting medications were cited by patients with RA as inconvenient activities that interfered with their "normal" lifestyle. This emphasizes the need to provide health spaces that provide comfort to the patient not only with regard to its environment, but also in its processes and flows, which, when optimized, can positively impact the patient's experience with the disease and their health outcomes.

\subsection{The experience of relationships with other people}

Regarding the "relationship with other people" aspect of Merleau-Pointy theoretical framework, most participants reported that they received support from the healthcare professionals. Tourmaline made it clear that the therapeutic relationship, guided by communication and listening, contributed to her adherence to pharmacotherapy:

"I felt safe. They (the physicians) make us feel safe. A lot of trust. They give you freedom to speak up, listen to you, explain and guide you. So I follow everything they say to the letter!" (Tourmaline).

The structure of "relationship to other" was translated by the bond developed between professionals and patients is fundamental for people to reach their therapeutic goals with their treatment. Several studies have indicated that establishing a relationship of trust with health professionals is an important step in patients' decision-making process regarding their pharmacotherapy (Brandester et al., 2016; Dohnhammar, Reeve \& Walley, 2016; Kobue, Moch \& Watermeyer, 2017; Pasma et al., 2015; Ramalho De Oliveira, 2011; Salt \& Peden, 2011; Voshaar, Vriezekolk, Dulmen, Bemt \& Laar, 2016). 
In a study by Salt and Peden (2011), the empathetic presence of healthcare professionals, their knowledge on RA, accessibility, communication and listening skills, kindness, mutual respect, genuine concern, and the patients' history of successful treatments were mentioned as useful for developing a trustful environment. With these attitudes, it is possible that patients understand why the changes in their treatment are necessary and how they can contribute to the progress of their health results (Brandester et al., 2016).

In contrast, negative experiences have a great impact on the adherence of these patients to pharmacotherapy. These experiences include inaccurate and contradictory information provided by healthcare professionals, provision of few therapeutic options, and unpleasant behavior during appointments (Barry, Stevenson, Britten, Barber \& Bradley, 2011, Salt \& Peden, 2011; Voshaar et al., 2016). Ruby, for instance, complained that the physicians from primary care did not evaluate him properly, neglected his pain and just renewed his prescription order.

Patients also experience relationships with other people by sharing their experiences with other patients. Emerald revealed how important this was for her acceptance of the treatment: "When I come here, I realize that I'm not alone... We talk: I have this condition too; I take this medicine... Well, I'm not the only one going through this, right? So we end up accepting it".

After experiencing several situations because of lack of information, Tourmaline seeks to be informed about her health condition, using social media to learn about the disease and its treatment, and is able to teach her fellow patients in the outpatient facility:

"Nowadays I read I do a lot of research. I want to know every single piece of news. There is this website that the people in the hospital help feed - Minas Gerais Rheumatology Society - and I follow all their posts. I wait all day long to see what they are going to post for us. Then I teach what I learn to people who are beginning their process now" (Tourmaline).

For Esmerald and Tourmaline, access to information greatly influences their experience. Patients with chronic conditions increasingly resort to the Internet to share their experiences with the disease and its treatment with other people who have the same problem, disseminate biomedical information, and give and receive support. This tool is a potential resource to help them make decisions and improve self-control in RA (Frossard \& Dias, 2016; Bordes, 2018).

\subsection{The experience of sexuality}

The power to decide is related to the energy that drives human beings, designated by Merleau-Ponty as "sexuality". The participants opt to use medications in an attempt to resolve or minimize pain, a frequent symptom, which paralyzes them and makes it impossible to carry out indispensable activities in their daily lives. Amethyst had to take care of her bedridden mother, so she explains:

"I keep taking the painkillers until it gets better. I take anything people say it's good for pain (...) I am not afraid; I am used to it. My mother is bedridden, so I need to take care of her and, if I'm in pain, how can I look after a person who depends on me for everything?" (Amethyst).

Agate bases the use of medication on her laboratory test results. She also questioned the need to use some of them, clearly distinguishing the medications she uses to treat RA from those used to treat other health conditions that have more "silent" symptoms: 
"You know, sometimes I need none of those! When the test results arrive then I realize the values are high! My triglycerides are like that. From now on, I will take those medicines correctly, just like I do with the medicines for arthritis, that cause me pain. I think it is because the other diseases show no symptoms; they are silent conditions" (Agate).

Zirconia demonstrated the ambiguity of the decisions that are made by all the participants about their medications at some point:

"Some days, I say to myself: Oh, this is not going to be useful! I am not taking it and that is it. Then, if I do not take the medication, I feel sick. I can see the consequences in the next day. I can't do anything! Then I go back to the starting point and tell myself: I cannot quit. The medicine has been good to me. Why should I stop taking it? So I keep bouncing back and forth" (Zirconia).

Patients with RA make decisions every day regarding their pharmacotherapy, motivated by current or previous experiences of using medications themselves, by the experiences of relatives or friends, information on the media, and society in general. Ultimately, patients are the ones who decide to use a medication or not; therefore, there is a need to better understand the decision-making process that patients develop regarding their pharmacotherapy (Nascimento et al., 2017, Ramalho-De-Oliveira, 2011; 2019; Salt \& Peden, 2011).

Pound et al. (2005) described how patients often "do experiments" with their drug regimens, modifying or regulating the administration of the medications by themselves. They often prioritize one medication over another and weigh the pros and cons of taking medications to try to gain control over their health condition (Elliott, 2008; Kobue, Moch \& Watermeyert, 2017; Pound et al., 2005). Also, by developing expertise on their health problems and medication use, patients begin to manage their treatment, making adjustments according to their needs (Shoemaker \& Ramalho De Oliveira, 2008). Studies have suggested that healthcare professionals must recognize that patients regulate themselves already, and, therefore, is necessary to build new knowledge together with the patient taking into account their previous experiences without judging their actions (Elliott, 2008; Kobue, Moch \& Watermeyert, 2017; Pound et al., 2005).

\section{Final Considerations}

The use of medications for RA had a significant impact on all the structures of human experience: time, space, relationships with other people, and sexuality, influencing the interviewed patients' decisions regarding pharmacotherapy. This study enables a better understanding of the patients' experiences that contributes to health professional carrying out interventions that are contextualized with the patient's life, helping to solve drug related problems and achieve better health outcomes. It is fundamental to emphasize the importance of the participation of the whole multidisciplinary team in the care of patients with RA, taking into account these experiences and valuing them in the pharmacotherapy decision-making process.

\section{Acknowledgments}

The authors wish to acknowledge the Federal University of Minas Gerais, for the financial support.

\section{References}

Alves, M. (2012). The medication experience of people living with HIV: From the understanding of the meanings of medication to the development of a conceptual framework of medication experience. Thesis, pharmacy, University of Minnesota. Minneapolis, USA.

Angermeyer, C. M. et al. (2001). Patients' and relatives' assessment of clozapine treatment. Psychological Medicine, 31(3), 509-517.

Arkell, P. et al. (2013) Patient experiences, attitudes and expectations towards receiving information about anti-TNF medication - "It could give me two heads and I'd still try it!' BMC Musculoskeletal Disorders, 14(165), 1-7. 
Research, Society and Development, v. 10, n. 9, e0110917071, 2021

(CC BY 4.0) | ISSN 2525-3409 | DOI: http://dx.doi.org/10.33448/rsd-v10i9.17071

Baker, F. K. et al. (2019) "Living a normal life": a qualitative study of patients' views of medication withdrawal in rheumatoid arthritis. BMC Rheumatology, $3(24), 1-8$.

Barry, A. C. (2001). Giving voice to the lifeworld. More humane, more effective medical care? A qualitative study of doctor-patient communication in general practice. Social Science and Medicine, 53(4), 487-505.

Bordes, A. K., J. et al. (2018). Assessing information needs and use of online resources for disease self-management in patients with rheumatoid arthritis: a qualitative study. Clinical Rheumatology, 37(7), 1791-1797.

Brandstetter, S. et al. (2016). The lesser of two evils...' - views of persons with rheumatoid arthritis on medication adherence: a qualitative study. Psychology and Health, 31(6), 675-692.

BRASIL. Ministério da Saúde. Secretaria de Ciência, Tecnologia e Insumos Estratégicos (2017). Protocolo clínico e diretrizes terapêuticas - Artrite Reumatoide. Portaria Conjunta n ${ }^{\circ}$ 15, de 11 de dezembro de 2017.

Bykerk V.; Emery P. (2010) Delay in receiving rheumatology care leads to long-term harm. RA and Rheumatism. Arthritis and Rheumatism, 62(12), 35193521.

Corrêa, K. A. (1997) Fenomenologia : Uma alternativa para pesquisa em enfermagem. Revista Latino-americana de Enfermagem, 5(1), 83-88.

Craftman, G. A. et al. (2015). Older people's experience of utilisation and administration of medicines in a health- and social care context. Scandinavian Journal of Caring Sciences, 29(4), 760-768.

Cypress, S. Brigitte (2011). The lived ICU experience of nurses, patients and family members: A phenomenological study with Merleau-Pontian perspective. Intensive and Critical Care Nursing, 27(5), 273-280.

Cock et al. (2014). A detailed analysis of treatment delay from the onset of symptoms in early rheumatoid RA patients. Scandinavian Journal of Rheumatology, 43(1), 1-8.

Creswell, W. J. (1998). Qualitative Inquiry and Research Design: Choosing Among Five Traditions. Thousand Oaks, CA: Sage.

Devins, M. G. (1994). Illness intrusiveness and the psychosocial impact of lifestyle disruptions in chronic life-threatening disease. Advances in Renal Replacement Therapy, 1(3), 251-263.

Devlen, J. et al. (2014). The Burden of In $\mathrm{fl}$ ammatory Bowel Disease : A Patient-reported Qualitative Analysis and Development of a Conceptual Model. Inflammatory Bowel Diseases, 20(3), 545-552.

Dohnhammar, U.; Reeve, J.; Walley, T. (2016). Patients' expectations of medicines--a review and qualitative synthesis. Health expectations, 19(2), 179-193.

Elliott, A. R. (2008). Poor Adherence to Medication in Adults with Rheumatoid Arthritis. Disease Management and Health Outcomes, 16(1), 13-29,

Feldman, H. C. et al. (2013). Assessing the need for improved access to rheumatology care: a survey of Massachusetts community health center medical directors. Journal of Clinical Rheumatology, 19(7), 361-366.

Guest, G.; Bunce, A.; Johnson, L. (2006). How many interviews are enough? An experiment with data saturation and variability. Field Methods, 18(1), 59-82

Gibson, G. (2016) "Signposts on the journey"; medication adherence and the lived body in men with Parkinson's disease. Social Science and Medicine, 152(C), 27-34.

Hallert, E. (2006). Disease activity, function and costs in early rheumatoid arthritis: The Swedish TIRA Project, Thesis, Faculty of Health Sciences, Linköping, University, Sweden.

Hewlett, S. et al. (2019). Dose reduction of biologic therapy in inflammatory arthritis: A qualitative study of patients' perceptions and needs. Musculoskeletal Care, 17(1), 63-71.

Hofmann, D. et al. (2015). Expectations of new treatment in rheumatoid arthritis: developing a patient-generated questionnaire. Health Expectations, 18(5), 995-1008.

Holland, P.; Collins, M. A. (2018). "Whenever I can I push myself to go to work": a qualitative study of experiences of sickness presenteeism among workers with rheumatoid arthritis. Disability and Rehabilitation, 40(4), 404-413.

Kalkan, A. et al. (2014). Factors influencing rheumatologists' prescription of biological treatment in rheumatoid arthritis: an interview study. Implementation Science, 9(153), 1-12.

Kobue, B.; Moch, S.; Watermeyer, J. (2017 ).“ It's so hard taking pills when you don't know what they're for ”: a qualitative study of patients ' medicine taking behaviours and conceptualisation of medicines in the context of rheumatoid arthritis. BMC Health Services Research, 17(303), 1-12.

Kumar, K. et al. (2011).“ It's like taking poison to kill poison but I have to get better ': A qualitative study of beliefs about medicines in Rheumatoid arthritis and Systemic lupus erythematosus patients of South Asian origin. Lupus, 20(8), 837-844.

Kvigne, K.; Kirkevold, M. (2003). Living With Bodily Strangeness: Women's Experiences of Their Changing and Unpredictable Body Following a Stroke. Qualitative Health Research, 13(9), 1291-1310. 
Research, Society and Development, v. 10, n. 9, e0110917071, 2021

(CC BY 4.0) | ISSN 2525-3409 | DOI: http://dx.doi.org/10.33448/rsd-v10i9.17071

Lard, R. L. (2001). Early versus delayed treatment in patients with recent-onset rheumatoid RA: Comparison of two cohorts who received different treatment strategies. American Journal of Medicine, 111(6), 446-451.

Lindén, C.; Björklund, A. (2010). Living with rheumatoid arthritis and experiencing everyday life with TNF- a blockers. Scandinavian Journal of Occupational Therapy, 17(4), 326-334.

Linden et al. (2010). Long-term impact of delay in assessment of patients with early RA. Arthritis and Rheumatism, 62(12), 3537-3546.

Marshall, N. J. et al. (2004). Patients' perceptions of treatment with anti-TNF therapy for rheumatoid arthritis: a qualitative study. Rheumatology, 43(8), 10341038

Matthews, E. (2011). Compreender Merleau-Ponty. (2. ed). Petrópolis: Editora Vozes.

Merleau-ponty, M. (2011). Fenomenologia da percepção. 4. ed. São Paulo: Editora WMF Martins Fontes.

Meyfroidt, S. et al. (2015). Patient Education and Counseling Patient experiences with intensive combination-treatment strategies with glucocorticoids for early rheumatoid arthritis. Patient Education and Counseling, 98(3), 384-390.

Minayo, S. M. C. (2014). O desafio do conhecimento: pesquisa qualitativa em saúde. São Paulo, SP: Hucitec.

Minayo, S. M. C. (2017). Amostragem e saturação em pesquisa qualitativa: consensos e controvérsias. Revista de Pesquisa Qualitativa, 5(7), 1-12.

Mota M. H., L. et al. (2017) Recommendations of the Brazilian Society of Rheumatology for the pharmacological treatment of rheumatoid arthritis. Advances in Rheumatology, 58(1), 1-17.

Nascimento, A., Y.; Silva D., L.; Ramalho-de-oliveira, D. (2020). Experiences with the daily use of medications among chronic hepatitis C patients. Research in Social and Administrative Pharmacy, 16(1), 33-40.

Nascimento, A., Y. et al. (2017b). A fenomenologia de Merleau-Ponty nas investigações sobre o uso de medicamentos: construção de uma cascata metodológica. Revista da Escola de Enfermagem da USP, 51(e), 1-8.

Nell et al. (2004). Benefit of very early referral and very early therapy with disease-modifying anti-rheumatic drugs in patients with early rheumatoid arthritis. Rheumatology, 43(7), 906-914.

Pasma, A. et al. (2015). Facilitators and barriers to adherence in the initiation phase of Disease-modifying Antirheumatic Drug (DMARD) use in patients with arthritis who recently started their first DMARD treatment. The Journal of Rheumatology, 42(3), 379-385.

Pinter, J. et al. (2017). Perspectives of Older Kidney Transplant Recipients on Kidney Transplantation. Clinical Journal of the American Society of Nephrology, 12(3), 443-453.

Polit, F. D. \& Chery, T. B. (2004). Nursing Research: Principles and Methods, (7th ed.). Philadelphia: Lippincott, Williams and Wilkins.

Pound, P. et al. (2005). Resisting medicines: a synthesis of qualitative studies of medicine taking. Social Science and Medicine, 61(1), 133-155.

Prothero, L. et al. (2016). Patients' and carers' views and expectations about intensive management for moderate rheumatoid arthritis: a qualitative study. Psychology, Health and Medicine, 21(8), 918-925.

Ramalho de oliveira, D. (2011). Atenção Farmacêutica: da filosofia ao gerenciamento da terapia medicamentosa. São Paulo: RCN.

Ramalho de oliveira, D. (2009). Experiência subjetiva com a utilização de medicamento (The Medication Experience): conceito fundamental para o profissional da Atenção Farmacêutica. Revista Racine, 19(113), 90-96.

Ramalho-de-oliveira, D. et al (2012). Preventing and resolving drug therapy problems by understanding patients' medication experiences. Journal of the American Pharmacists Association, 52(1), 71-80.

Raza K. et al. (2011). Delays in assessment of patients with rheumatoid RA: Variations across Europe. Annals of the Rheumatic Diseases, 70(10), 1822-1825.

Salt, E.; Peden, A. (2011). The Complexity of the Treatment: The Decision-Making Process Among Women With Rheumatoid Arthritis. Qualitative Health Research, 21(2), 214-222.

Santos; R., S. (1999). Qualitative and quantitative methods in biomedical research, Jornal de pediatria, 75(6), 401-406.

Sanders, P. (1982). Phenomenology: a new way of viewing organizational research. Academy of management review, 7(3), 353-360.

Senna, R. E. et al. (2004). Prevalence of rheumatic diseases in Brazil: a study using the copcord approach. Journal of Rheumatology, $31(3)$, $594-597$.

Shaw, Y. (2018). Rheumatoid arthritis patients' motivations for accepting or resisting disease-modifying antirheumatic drug treatment regimens. Arthritis Care and Research, 70(4), 533-541.

Shoemaker, J. S.; Ramalho de oliveira, D. (2008). Understanding the meaning of medications for patients: the medication experience. Pharmacy World and Science, 30(1), 86-91.

Singh, A., J. et al. (2016). American College of Rheumatology Guideline for the Treatment of Rheumatoid Arthritis. Arthritis Rheumatology, 68(1), 1-26. 
Research, Society and Development, v. 10, n. 9, e0110917071, 2021

(CC BY 4.0) | ISSN 2525-3409 | DOI: http://dx.doi.org/10.33448/rsd-v10i9.17071

Smolen, S., J. et al. (2017). EULAR recommendations for the management of rheumatoid arthritis with synthetic and biological disease-modifying antirheumatic drugs: 2016 update. Annals of the Rheumatic Diseases, 76(6), 960-977.

Todd, A. et al. (2016). I don't think I'd be frightened if the statins went': a phenomenological qualitative study exploring medicines use in palliative care patients, carers and healthcare professionals. BMC Palliative Care, 15(13), 1-7.

Turato, E. R. (2005). Métodos qualitativos e quantitativos na área da saúde: definições, diferenças e seus objetos de pesquisa. Revista de Saúde Pública, 39 (3), 507-514.

Van Aken et al. (2004). Radiological outcome after four years of early versus delayed treatment strategy in patients with recent onset rheumatoid arthritis. Annals of the Rheumatic Diseases, 63(3), 274-279.

Voshaar, M. et al. (2016). Barriers and facilitators to disease-modifying antirheumatic drug use in patients with inflammatory rheumatic diseases: A qualitative theory-based study. BMC Musculoskeletal Disorders, 17(1), 1-12. 